遊離腹直筋皮弁を用いた口腔癌即時再建の経験

一一特に大胸筋皮弁との比較

長谷川和樹・天笠 光 雄*・新井田俊雄*

岩城 博*・塩田重利*

\title{
Microvascular reconstruction with the rectus abdominis myocutaneous flap after oral cancer ablation
}

\author{
Kazuki Hasegawa - Teruo Amagasa* - Toshio Araida* \\ Hiroshi IWAKI* - Shigetoshi ShIOdA*
}

\begin{abstract}
The rectus abdominis myocutaneous flap based on the inferior epigastric vessels was applied for reconstruction after oral cancer ablation. In all 5 cases, the flaps were successfully transplanted without any necrosis. This flap showed advantages compared to pectoralis major myocutaneous flap, deltopectoral flap and others. The advantages include: 1) The large skin paddle could be taken with good blood supply. 2) The inferior epigastric vessels were anatomically constant with adequate length and size for anastomoses as the nutrient vessel. 3) The muscle volume could be adjusted. 4) All these procedures, such as tumor ablation, elevation of flap, reconstruction etc. could be simultaneously performed in a supine position.

We briefly reported the technique of elevating rectus abdominis myocutaneous flap, clinical course in five cases of the rectus abdominis myocutaneous reconstruction and advantages and disadvantages of this flap.

Our experience suggested that the rectus abdominis. myocutaneous flap was one of the most suitable flaps for recostruction after ablation of oral cancer.
\end{abstract}

Key words: rectus abdominis myocutaneous flap (腹直笳皮犵), Microvascular reconstruction (澱小血管外科による再建), oral cancer (口腔癌)

緒

言

近年再建外科の進歩はめざましく，口腔外科領域でも

甫立洋岡病院口腔外科

（主任：長谷川和㴻科長）

* 東京医科消科大学檤学部第 1 口腔外科学教空 （主任：塩田重利教授）

Department of Oral and Maxillofacial Surgery, Shizuoka City Hospital (Chief: Dr. Kazuki Hasegawa)

* The First Department of Oral and Maxillofacial Surgery, Faculty of Dentistry, Tokyo Medical and Dental University (Chief: Prof. Shigetoshi Shioda)

受付日：平成元年 7 月 24 日
D-P 皮弁，大胸筋皮弁をはじめとしさまざまな皮弁，筋 皮弁が用いられるよらになった。さらに，微小血管吻合 による遊離皮弁, 遊離筋皮弁の開発, 普及により, 再建 する部位，範用などの違いからより適切な皮弁，筋皮升 が選択できるよらになってきた。

われわれは口腔癌切除後に逝離腹直管皮弁を用い, 即時 再建を行った 5 例を経験し良好な結果を得たので報告す 万.

\section{手 術 術式}

\section{1. 皮弁のデザイン}

皮島 (skin paddle) の作図としては, 比較的太い穿通 枝が集っている胎周囲を基部として皮島を設定する。

馏部から肩甲骨下縁にいたる外側斜上方向にて設定す るほか, 臍周囲を含め, 腹直筋上に沿う上下方向か, 横方 


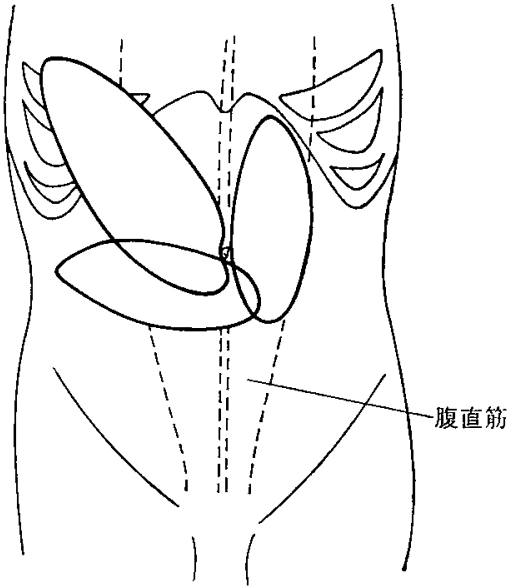

図 1 腹直筋皮弁の皮島のデザィン

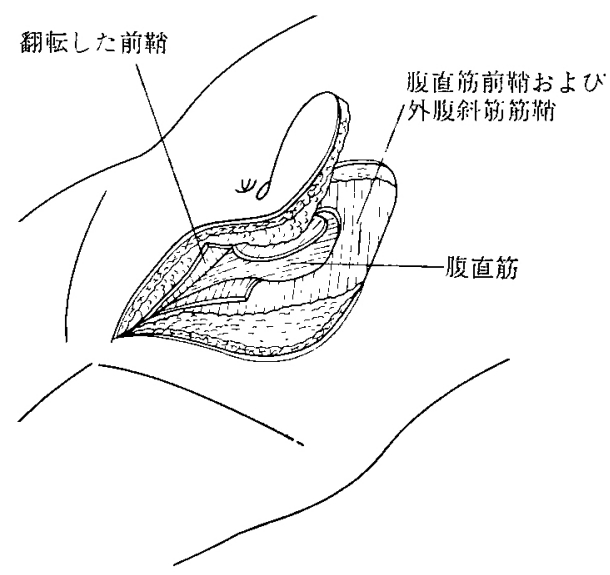

図 2 皮島を挙上し腹直筋前蝺に切開を加えると， 腹直筋の筋体が露出する。

向などが用いられる（図1 $)^{1 \sim 5) . ~}$

\section{2. 皮弁の举上}

まず切開線にそって上方括よび外側に皮膚切開を加克 腹直筋前䩗および外腹斜筋の筋膜上にいたる。次いで，外 側より皮手を皮下脂肪層の下のレベル，すなわち外腹斜 管腱膜および腹直筋筇䩗上で，滕周团に向かい皮膚を剥 離举上してゆく，前䩗の皮弁側につける部位をで虽離し

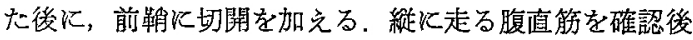
さらに前䩗の綎切開を下方に伸ばし，前䩗を開く(図 2). 腹直笳の外側縁を確認し, 手指にて筋体稟面之後䩡との 間を鈍的飞剩離する。この際，後鞘より出て腹直筋外側 に入りこむ肋間神経 (運動枝), 動静脈が確認できるが, 筋体を温存する時以外は切断することになる．腹直筇筋 体を外側より举上すると裹面を走る下腹壁動静脈が確認 できる（写真１）。また弓状線付近でも外腸骨動静脈に

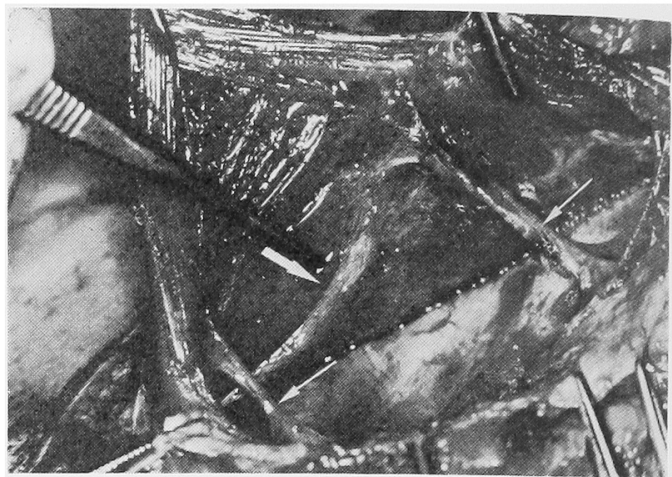

写真 1 腹直笳の裹面に下腹壁動静脈（太い矢印） と，後䩗より出て腹直筋の外側へ入りこむ 肋間神释，動静脈 (細い矢印) がみよらる。

向から下腹壁動静脈の血管柄が腹直筋の外側縁汇容易に 確認できる。

皮島の残りの上端，正中側（臍部側）そして下端部の 皮膚切開を前䩗に至るまで加える，穿通枝は1〜2本を 残せばよいといわれているが，確認が困難な場合，胎周

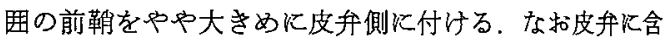
まれる前鞘の下端は，術後の一ルニアを防ぐため，腹直 筋後䩗が如如し腹膜のみになる弓状線より上方にくるよ らにする．前鞘の全周を切開した後，下腹壁動静脈の筋 体の流入部から穿通枝を含む部分の血管を損傷しないよ らに注意しながら，必要に応じた筋体の量を皮弁側に残 し，腹直筋筋体を上端より少しずつ切断，結禁し，さら

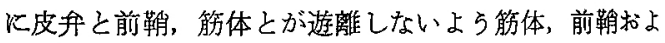
び皮境を数か所释合固定する，次いで，正中側(臍側)を 同棣に切離すると筇皮弁は上方より翻転が可能となり， 下腹壁動消脈とその筋体襄面の流入部の観察がより容易 となる(图了).

最後に下腹壁動鋂脈の筋体流入部よりやや下部にて皮 弁に含む腹直筋の下端を切離し，島状皮弁とする(図 4).

な扣腹直筋筇体を少なめにする場合は，数本の穿通枝 を確認後，その外側にて前䩗に切開を加兄，前䩗を開 き，穿通枝を傷つけないように注意しながら，腹直筋を 鈍的に裂くよ5にして綎に分ける，次いで㬳体の裏面に て下腹壁動静脈よりの派生部をみつけ，穿通枝と下腹壁 動静脈とのつながりを傷つけないよ5に筋体を切断す る。この操作により筋体の内，外側部が保存できるとと になる ${ }^{3,4)}$.

次いで上腹壁動静脈の血管柄を血管径の太くなる外腸 骨動静脈の派生部まで分枝を結禁切断しながら㔀離，外 腸骨動数脈側は結棌し，皮弁側の血管にマイクロクリッ プをかけ切断する。なお島状皮升となったところで皮升 の血行と止血老確認して扣く，また血管柄の剝離海し 必要に応じて外腸骨動脈方向へ，皮潧扣よび前鞘の岈開 


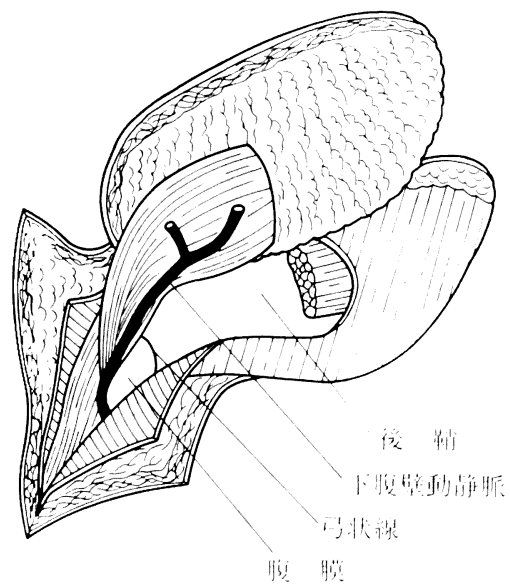

图 3 腹直管管体の上端打よび正中側它切断し 翻転すると筋体の蓑面に下腹壁動棦脈が 確認できる。

を追加する。

\section{3. 腹部の創閉鎖}

腹膜の穿孔がないことを確認後, さらに微温生食水に て創部をよく洗浄し，再度止血を確㤮する。次いで前䩗 を密に縫縮する，われわれは前䩗の両外側縁に系をかけ しっかりと寄せ，さらにたるんだ前䩗の辺縁部を他方の 下に引きこみ，互いに重なり合うようにし雨者の辺縁を 密に縫合している。な持続吸引ドレーンチューフを後 䩗上と前靴上にそれぞれ1本ずつ留置する，次いで皮下 释合，皮虞縫合を行い創の閉鎖を完了する。

\section{4. 口腔の再建}

まず予した位置に皮升をおき，㓣を閉鎖した状態で 皮升が欠損部に納まり，下嘖や周囲組織にて血管柄が圧 迫されないか，またこの状態で皮弁の血管柄と recipient vessel とが吻合可能かを確認する。

次いで，皮島を口腔の後方より前方に向かい縫合して いく，なお皮弁と口底粘膜，雨肉，下顎骨などが接する 部位は術後に摭孔を形成しやすいため特に注意して縫合 寸る。

舌を后籁に切除した場合は再建舌を全体に盛り上げた 状態で形成し，また下顎骨内側から顎下部，オトガイ下 部にかけて死腔ができないように筋体の辺緑を数か所周 田組織汇縫合固定し補填する。

皮弁の縫合がほぼ終了したところで，微小血管响合に 移る。

\section{5. 血管吻合}

血管吻合は影改鏡下で 4 倍から16倍程度の倍染にて行 5.下腹壁動脈との吻合血管としては主に浅頸動脈と上 甲状腺動脈を用い, 症例によっては顔面動脈なとも用い た。また下腹壁静脈は主に外頸静脈と吻合したが，その

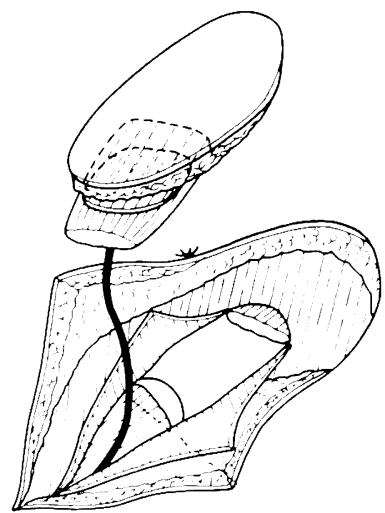

Fing tion

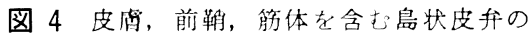
等上小完了。

他に前頸静脈や内頸静脈の枝である上甲状腺静脈も用い た。物合は 10-0 のナイロン系を用い動静脈それぞれ普 通12針から16針の释合を行らが，縫合数は血管径や，下 腹壁動静脈と吻合血管との血管径の違いなどによっても 異なる。

症

例

対象症例は1988年 6 月より1989年 2 月までの 8 か月間 飞東京医科荬科大学第 1 口腔外科比いて遊離腹直筋皮 弁を用い即時再建を行った舌扁平上皮癌 5 症例である (表1).

その内訳は表 1 のごとく舌亜全摘 2 例, 舌全摘 2 例拉 上び舌半側切除と䫇下部皮䖉切除であり，皮并の大きさ は $11 \times 7 \mathrm{~cm}$ から $17 \times 8 \mathrm{~cm}$ まで少られた。皮并は全例 が完全に生着した。このらちの代表的な 3 症例につき概 説する.

症例 $1: 53$ 歳 男性.

主 訴：左舌の難治性口内炎。

家族歴・既往歴：特記すべき事項なし。

現病歴: 䄪 9 只月ぼ前に左舌側縁に口内炎様の無痛 性溃瘍に父でくも放置した。2 か月前に内科を受診した ところ軟育を処方されたが症状は改善せず，別の内科よ り紹介され当科を受診した。

口腔外所見: 体格, 栄差中等度. 顔貌左右刘称. リン 節所見としてはオトガイ下部に小指頭大のリン八節が 触知され，動きに制限が認められた。

口腔内所見. 左舌側縁に溃勛を伴った $45 \times 19 \mathrm{~mm}$ の 硬結を認めた。

初診時臨床診断：左舌腫瑒（T 3 N $1 \mathrm{M} 0$ )

処置および経過：術前化学療法として peplomycin 30 $\mathrm{mg}$, Adriamycin $30 \mathrm{mg}$, Cis-platinum $100 \mathrm{mg}$ を投与した 後, GOE 企身麻酔下に, 気管切開, 舌亚全摘, 左口底切 
表 1 腹直筋皮弁症例の内訳

\begin{tabular}{|c|c|c|c|c|c|c|}
\hline 症 例 & 性 & 病 ${ }^{\text {名 }}$ & 手 & 皮島の大きさ & recipient vessel & 結 果 \\
\hline 1 & $\begin{array}{l}\text { 男性 } \\
53 \text { 歳 }\end{array}$ & $\begin{array}{c}\text { 左舌 癌 } \\
\text { T } 3 \text { N } 1 \text { M } 0\end{array}$ & 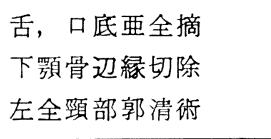 & $11 \times 7 \mathrm{~cm}$ & $\begin{array}{l}\text { 浅頸動脈 } \\
\text { 外頸静脈 }\end{array}$ & 完全生着 \\
\hline 2 & $\begin{array}{l}\text { 男性 } \\
34 \text { 歳 }\end{array}$ & $\begin{array}{c}\text { 右 舌 癌 } \\
\text { T } 3 \text { N } 2 \text { cM } 0\end{array}$ & $\begin{array}{l}\text { 舌, 口底亜全摘 } \\
\text { 下顎骨辺縁切除 } \\
\text { 左保存的頸部郭清犹 } \\
\text { 右全頸部郭清術 }\end{array}$ & $11 \times 7 \mathrm{~cm}$ & $\begin{array}{l}\text { 浅頸動脈 } \\
\text { 外頸静脈 }\end{array}$ & 完全生着 \\
\hline 3 & $\begin{array}{l}\text { 男性 } \\
42 \text { 歳 }\end{array}$ & $\begin{array}{c}\text { 左舌 癌 } \\
\mathrm{T} 2 \mathrm{~N} 2 \mathrm{bM} 0\end{array}$ & $\begin{array}{l}\text { 左舌口底半側切除 } \\
\text { 下顎骨区域切除 } \\
\text { 左顎下部皮膚切除 } \\
\text { 左全頸部郭清術 }\end{array}$ & $13 \times 8 \mathrm{~cm}$ & $\begin{array}{l}\text { 顔面動脈 } \\
\text { 前頸静脈 }\end{array}$ & 完全生着 \\
\hline 4 & $\begin{array}{l}\text { 女性 } \\
43 \text { 歳 }\end{array}$ & $\begin{array}{c}\text { 右 舌 痹 } \\
\text { T } 4 \text { N } 2 \text { bM } 0\end{array}$ & $\begin{array}{l}\text { 舌, 口底全摘 } \\
\text { 下顎骨区域切除 } \\
\text { 右全頸部郭清少 } \\
\text { 左上頸部郭清術 }\end{array}$ & $11 \times 7 \mathrm{~cm}$ & $\begin{array}{l}\text { 上甲状腺動脈 } \\
\text { 上甲状腺静脈 }\end{array}$ & 完全生着 \\
\hline 5 & $\begin{array}{l}\text { 男性 } \\
43 \text { 嵗 }\end{array}$ & $\begin{array}{c}\text { 右舌 癌 } \\
\text { T } 4 \text { N } 2 \text { cM } 0\end{array}$ & $\begin{array}{l}\text { 舌, 口底全摘 } \\
\text { 下顎骨区域切除 } \\
\text { 軟口蓋・咽頭側壁 } \\
\text { 部分切除 } \\
\text { 右保存的頸部郭清術 } \\
\text { 左全頸部郭清術 }\end{array}$ & $17 \times 8 \mathrm{~cm}$ & $\begin{array}{l}\text { 上甲状腺動脈 } \\
\text { 外頸静脈 }\end{array}$ & 完全生着 \\
\hline
\end{tabular}

除, 下罘骨辺縁切除, 左全頸部郭清術を施行し, $11 \times 7 \mathrm{~cm}$ の皮島を持つ遊離腹直筋皮弁にて舌の再建を行った（写 真 2，3，4，5，6). な拈血管吻合は，6〜8 倍の顕徽鏡 下にて下腹壁動脈と浅頸動脈, 下腹壁静脈と外頸静脈を 10-0ナイロン釆にてそれぞれ14針ずつ綘合を行った。

術後経過: 術後経過は良好で術後 2 週で気管カニュー レを抜去し， 3 週目で経口可能となり，4 週目に軽快退 院した。現在言語機能も比較的良好で元の職業に復帰し ている。な挴術後 1 年 2 か月後の現在まで腫瘍の再発は ない。

症例 3:42歳 男性.

既往歴：5 年前左白内障の手術を受けている.

家族歴：特記事項なし。

現病歴: 初診の 7 か月前に左舌側縁に疼痛が出現し た. その後徐々に疼痛が增強したため近医を受診し, 当 科を紹介される。

口腔外所見: 体格中等度. 左顎下部に鵎卵大, 弾性硬

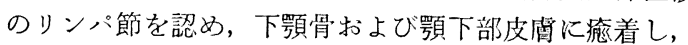
圧痛を伴っていた。

口腔内所見：左舌侧縁に溃序拉よび白斑を伴う $26 \times 20$ $\mathrm{mm}$ 大の比較的境界明膫な硬結が認められた。
初診時臨床診断 : 左舌腫湟 ( $\mathrm{T} 2 \mathrm{~N} 2 \mathrm{aM} 0$ ).

処置および経過：NLA 全身麻醉下に気管切開，左全 頸部郭清術, 舌・ 口底半側切除術, 下䫇骨区域切除拈よ び $60 \times 50 \mathrm{~mm}$ の顎下部皮䖉を en bloc 飞切除した。 な 括保存する予定の外頸静脈は腫瘍の浸潤のため見い出世 なかった。再建については, A-O Plate にて下靧の扁位 防止を計った後, $13 \times 8 \mathrm{~cm}$ の皮島を持つ腹直筋皮并 を臍周囲のみに筋肉を付的举上，一部皮島の中央部を deepithelization 乙，筋体のある部分で䫇下部皮虞を再建 した。さらに舌は先端を一部縫縮し舌尖を形成した後, 筋体の付着していない部分で残りの舌の欠損部を再建し た（写真 7，8）。血管吻合は下腹壁動脈を上甲状腺動脈 と，下腹壁静脈は鎖骨上部に認められた静脈と吻合し た。術後皮弁の色調は良好であったが，血行が再開され てから約 7 時間後に, 皮弁に点状の出血斑が出現した。 静脈血栓が嶷われたためべッドサイドにて直ちに頸部の 創を開き，静脈吻合部の血栓を確認した。吻合部を切断 しへパリン生食にて皮弁側の血管内を洗浄したところ， 良好な粼脈血の流出が認められたため, 再吻合まで出血 したままの状態とした。動脈の吻合部の血行は良好であ ったが，反対側の顔面動脈と前頸静脈に再吻合した，再 


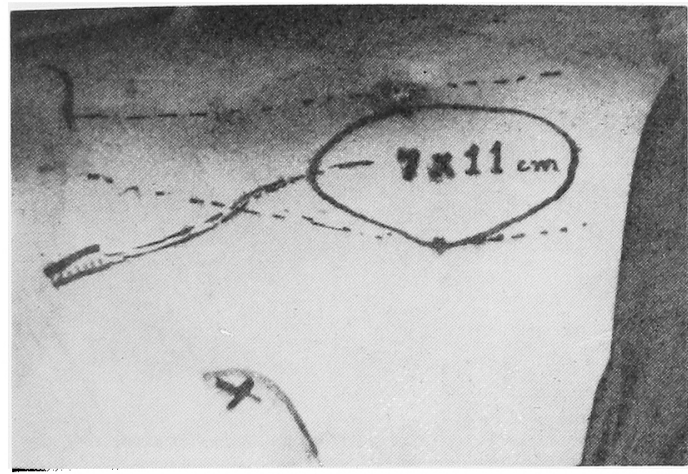

写真 2 症例 1 の皮弁のデザイン

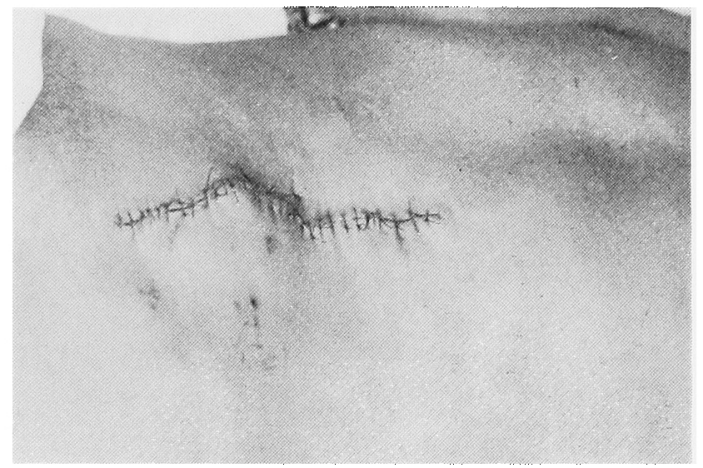

写真 3 症例 1 . 腹部の飤

吻合後の経過は良好で，直後から皮弁の色調は改善傾向 汇すり，7日後には出血斑は消失した。術後 7 日目に気 管切開部を閉鎖し，嚥下機能も回復してきたため術後 4 週目にて軽快退院した。

退院後頸部に外照射 $40 \mathrm{~Gy}$ 行い，9 か月後の現在経 過良好である。な挌，術後再建舌の発毛を認めた（写真 9）か，技毛し発毛恃徐々飞減少㑯向にある，腹部につ いては下腹部にごく軽度の膨隆があるものの，全く支障 なく日常生活を送っている。

症例 5:41歳 男性.

既往歴・家族歴：特記事項なし

現病歴：初診より 7 か月程前より左舌側緑部がしみる ようになった。症状が改善しないため 5 か月前某病院耳 鼻科を受診し手術を针められるが，海外出張のため拒 否．その後䫇下部に腫脹が生じたため同科を再度受診 し，放射線科を紹介される．同放射線科上り当大学医学 部放射線科を経て当科沼介される。

口腔外所見：体格中等度，顔色良好．左顎下部治中指 頭大拉よび示指頭大の非可動性で弾性硬のリンパ節を， また在側の中深頸部に弾性硬で指頭大のリンパ節を触 知した。

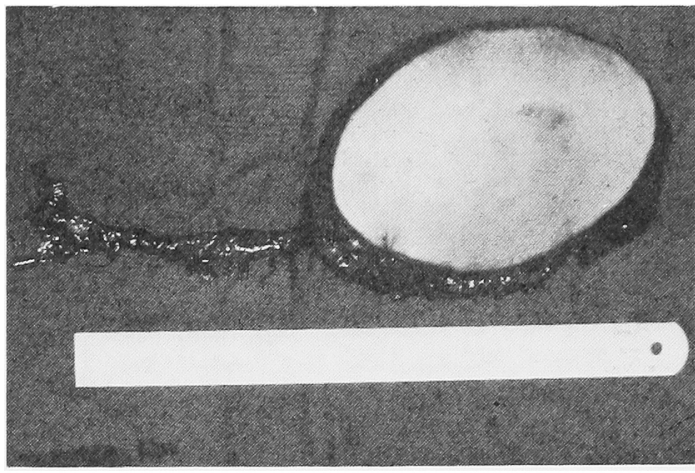

写真 4 症例 1. 皮弁の前面

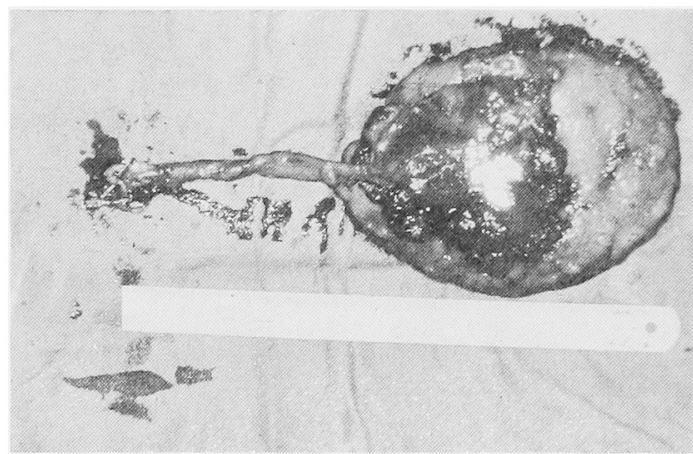

军真 5 症例 1 . 皮弁の衰面

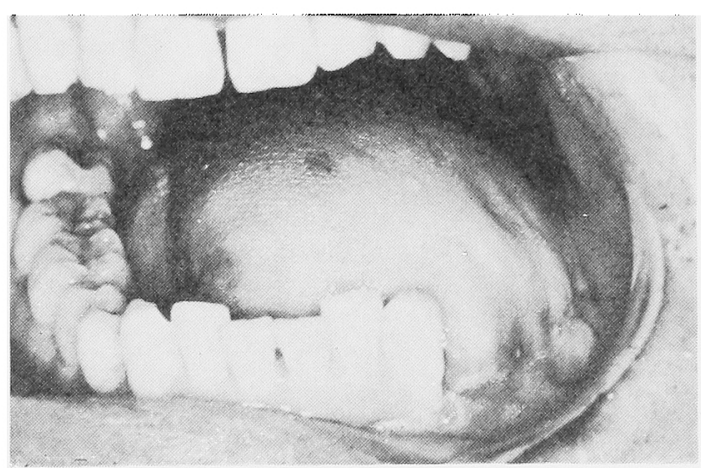

写真 6 症例 1 . 㭪後 6 加の口腔内

口腔内所見：硬結快可動部舌の $4 / 5$ を占め，一部舌根 部に及えでいた，舌に著名な運動障害を認め，さらに無 下困難, 言語機能障害も譛められた。

初診時臨床診断：左舌稙痬（T 4 N 2 cM 0)

処置および経過：全身麻醉下に右内頸静脈を保存し た頸部郭清術, 左全頸部郭清術, 下顎骨区域切除術, 舌・ 口底全摘，軟口蓋・咽 頭 側壁 部分切除術を行った，再 


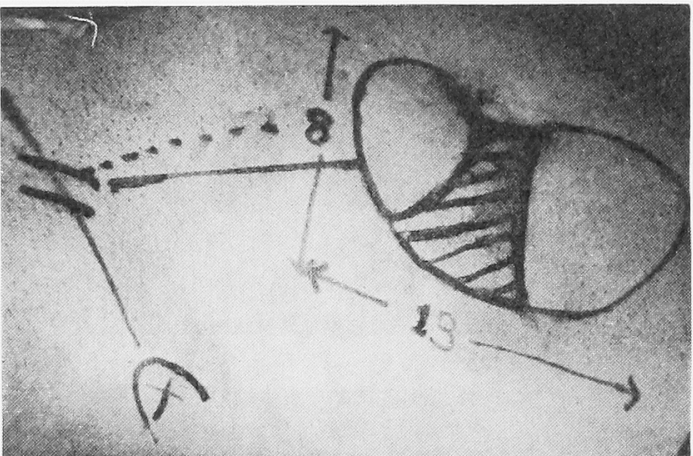

写真 7 症例 3 の皮弁のデザイン

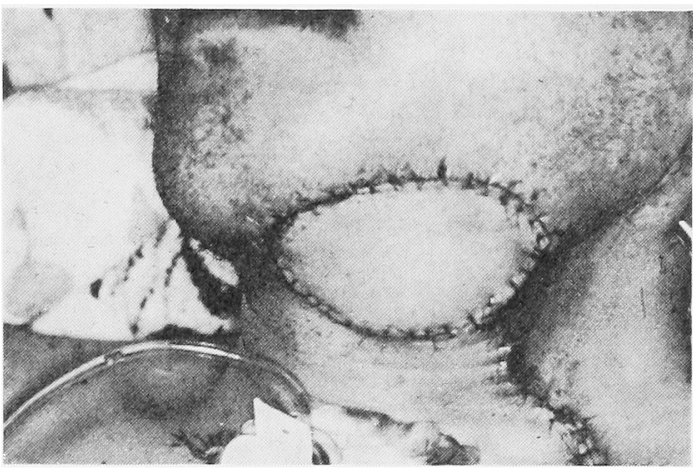

写真 8 再建された䫇下部皮膚

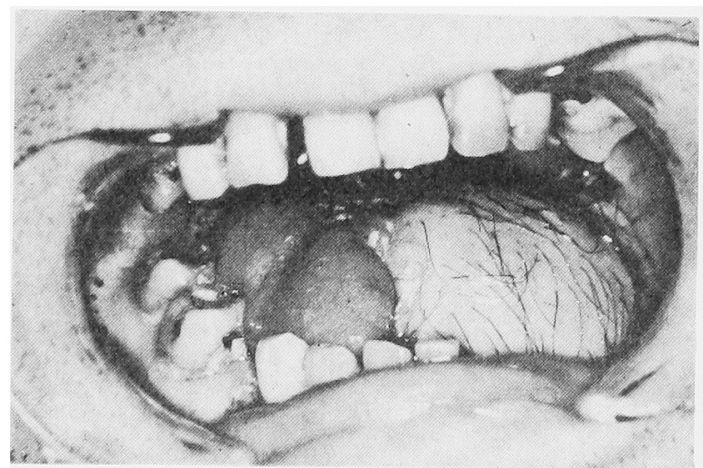

写真 9 街後 3 か月の口腔内

建は輪状咽頭筋切除，喉頭挙上 ${ }^{6)}$ を行った後， $17 \times 8 \mathrm{~cm}$ の皮島を持つ腹直筋皮弁を用いて行った（写真 10，11， 12). 軟口蓋と咽頭側壁は筋体の付着していない部分の 皮島にて再建し，舌は一部筋体の付着した部分にて再建 した. なお，再建した下顎内側の死腔は筋体を数か所綘 合固定して充填した。

血管吻合の動脈は上甲状腺動脈を，静脈は外頸静脈を recipient vessel として用いた。

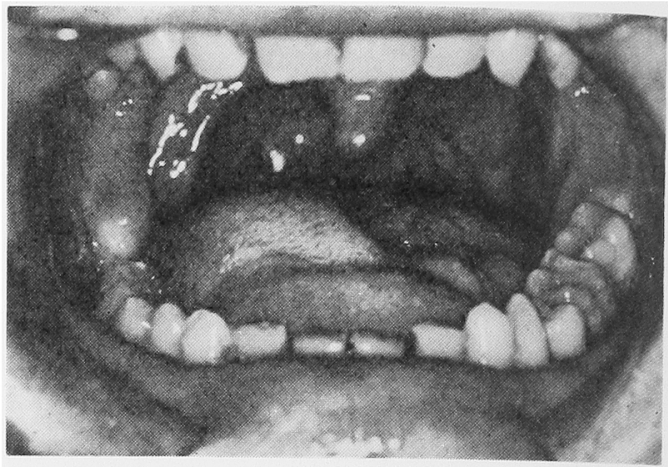

写真 10 症例 5 の初診時の口腔内

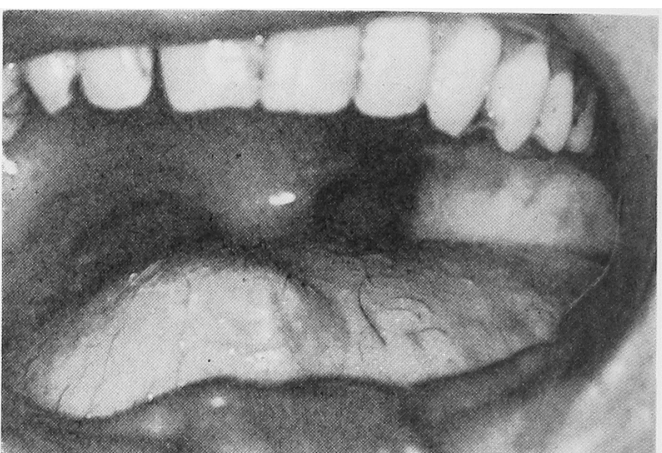

写真 11 街後 3 か月の口腔内

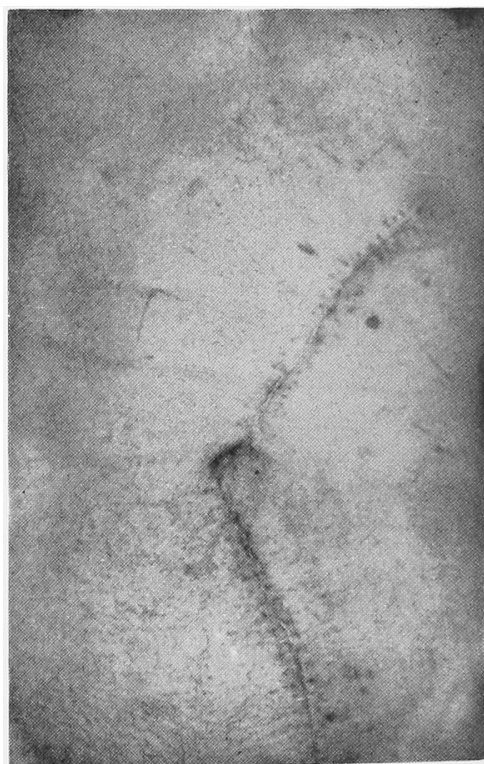

写真 12 術後 1 か月の皮弁採取部

術後経過は良好で，皮弁は一部の壊死むなく完全飞生 着し，渑孔も生していない。衍後 1 週間目には歩行可能 
となり,さらに 4 週目で热下可能となった。なお, 再建 した咽頭側壁は軟口蓋の動きとともに良好な可動性を示 している。術後 5 か月と観察期間は短いが, 腫瘍の再発 はない、

\section{合併症}

症例 2 に術後腹部の創感染を吠めたため,ドレナージ し，1日 2 回の洗浄を続けたところ約 1 週間で創は自然 閉鎖した。しかし同症例では，術後約 4 か月頃より前䩗 の弛緩による下腹部の膨隆が生じ，本学外科にて修正手 術を施行し現在は経過良坶である。なお現在は薏職とし て元の賎場に復帰している.

さらに症例 3 で静脈の血栓を認めたが，早期に発見で き再吻合したため，皮弁は完全生着した。

なお術後の観察期間は短いものの, 全例原発采の再発 はみられていない。ただし症例 4 では術後反対側の頸部 リンパ節転移が生じ，全頸部郭清術を施行している。

\section{考察}

これまで口腔癌切除後の再建には，D-P 皮弁，大胸朌 皮弁あるいは広背筋皮弁が主に用いられてきた。しかし D-P 皮弁は 2 回の手術を要し入院期間が長くなり,さら に恵皮部に植皮が必要なことなど難点があった7)。次い で登場した大胸笳皮弁は皮弁採取部の一期的䋖縮，そし て一期的再建が可能であり, 最も広く口腔外科領域でも 用いられるよらになった ${ }^{8)}$. しかし，同筋皮弁は必ず皮 島直下に筋肉がつき bulky になりすぎたり，大きな皮 弁が必要となった時, 部位によっては皮弁の再建部への 到達が困難であったり，皮島のデザインを大胸筋の下縁 より下方に設定すると末梢部は血行の不安定な random pattern となり，辺縁の壊死や唒孔を起こしたりするこ となどの問題があっだ)。これらの問題点をある程度解 決したのが腹直筋皮弁であると思われる.

腹直筋皮弁は，はじめ上腹壁動静脈を栄坫血管とした 有茎皮弁として乳房再建などに用いられていた ${ }^{9,10)}$ 乙 の後1983 年に Taylor ${ }^{1)}$, Boyd ら ${ }^{2)}$ により下腹壁動静脈

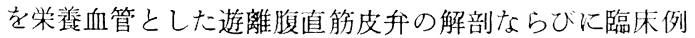
が詳細に報告され，さまざまな部位の再建に広く用いら れるよらになった。

\section{1. 皮弁の挙上}

皮島の採取可能な範用として Taylor ら ${ }^{1)}$ は外側は前 腋窩線まで，内側は反対側の腹直筋外側縁まで，安全に 用いることができると報告している。また朴，波利井 ら 3 は体型により異なるが，通常の成人では長さ $20 \mathrm{~cm}$, 幅 $12 \mathrm{~cm}$ の大きさまでは十分な血行が得られ，皮弁と して安全に用いることができると述べている。ささらに梶 川 ${ }^{11)}$ は， $28 \times 12 \mathrm{~cm}$ の島状下腹直筋皮弁による再建例
を報告している。われわれの症例でも $11 \times 7 \mathrm{~cm}$ から $17 \times 8 \mathrm{~cm}$ までの大きさの皮島を用いたが，皮弁の血行 および皮弁の到達などには全く問題なく再建できた。皮 弁採取に際しては，比較的太い前鞘穿通枝が臍周因に集 中して扣り，これらの穿通枝の $1 \sim 2$ 本を温存するたけ でかなりの大きさの皮弁が栄着されることになる3 ${ }^{3,4,12)}$. 前䩗瑏通枝が含まれる部分の及皮弁に残せばよく，皮 島や朌体の大きさに一致させる必要はないと思われる。

なお，皮弁採取可能な大ささは，一期的に維縮可能な 範囲で決められるが，口腔癌再建で用いられる皮弁とし ては，大きさが問題になることはほとんどないと思われ る.

\section{2. 血管吻合}

血管柄のねじれを防ぐため，皮弁にて口腔を再建した 後に血管吻合を行った。 recipient vessel として動脈は上 甲状腺動脈, 浅頸動脈, 顔面動脈を, 静脈は外頸静脈, 前 頸静脈，上甲状腺静脈を用いた。栄坫血管である下腹壁 動脈は 1 本で，これに伴走する下腹壁静脈は 2 本で外腸 骨静脈よりの派生部直前で 1 本となるものが多い, $1,2,5)$ Boyd ら ${ }^{2)}$ によると, 下腹壁動静脈の外腸骨動静脈から の起始部での平均血管径は，動脈が $3.4 \mathrm{~mm}$ で，静脈 は 2 本の場合 $2.5 \mathrm{~mm}$ で，1本となる場合 $4.4 \mathrm{~mm}$ と 報告されている。われわれの経験した症例では，静脈は 2 本で外腸骨静脈よりの派生部付近で 1 本となるものが 多く, 1 例のみが 2 本のままで外腸骨静脈に流入してい た。 また，下腹壁静脈は外腸骨静脈より離れると，外頸 静脈と比較してやや細く，そのため外腸骨静脈の派生部 ぎりぎりの部位で 1 本になったところで切断して用い た。

\section{3. 遊離腹直筋皮弁の特徵}

本皮弁の利点をあげる ${ }^{125)}$ と,

1）口腔外科領域の再建としては十分な大きさの皮弁 の採取が可能で，しかも良好な血行が得られる。

2 ) 筋皮弁の栄盖血管の走行が安定しており，挙上が 容易である。

3 ）長い血管柄が得られ，再建部までの到達に問題が ない。

4) 下腹壁動静脈の血管径が太い.

5）皮弁に付ける筋肉のボリュームが調節できる。

6 ）皮弁採取部は一期的縫維が可能である。

7 ）体位交換を必要としない

8）口腔と皮尣採取部が離れており，同時に皮升採 取，創の閉鎖が可能である.

欠点としては

1）下腹部の膨隆や腹壁症痕へルニアの発生する可能 性がある。

2) 肥満の患者では皮下脂肪が厚く, 皮升も厚くな る.

3）発毛をみることがある。 
われわれは本皮弁を主に舌半側より大きな舌西全摘や 舌全摘症例および広籁囲欠損症例なとに適応してきた。

従来，われわれはこのような症例の再建には主に大胸 筋皮弁を用いてきたので，本皮弁と大胸筋皮弁の利点と 欠点につき両者を具体的に比較梌討してみた。腹直筋皮 弁が大胸筋皮弁より㑮る点としては，（1）血行のよいか なり大きな皮弁が採取できる，(2) 血管柄が長いため皮 弁の位置が自由に選択できる（再建部への到達に問題が ない)，(3）筋体の量が調節できる，(4) 乳房の変形が起 きないなどがあげられる8 。ささらに，大胸筋皮弁では時 として笳肉莨の症痕拘縮により機能障害が生じる このような問題もない，舌西全摘例なとを大胸筋皮弁で 再建すると術後筋肉の萎樎による再建舌の著明な平坦化 がみられるが，腹直筋皮弁ではやや厚めの皮闻を主体と して再建寸るため萎縮の程度も比較的少ないと考えられ る。また皮弁採取部も口腔, 頸部より離れているため腫 瘳切除と皮弁举上，腹部閉鎖と同時に容易に行元る利点 があると考古られる。逆に大胸矨皮弁が腹直矨皮弁より 偄る点としては，（1）胁骨や胸骨を同時に移植できる，

(2) 筋肉茎により頸部郭清術後の頸動脈の保護が可能で ある，(3）微小血管吻合を必要としない。などがあげら れる ${ }^{8)}$. しかし, 梁井, 波利井ら ${ }^{14}$ は, 頭頸部領域の再 建に用いられる有茎皮弁と遊離皮弁の成䋶を比較する と, 遊離皮弁に比へ有茎皮弁は皮弁の壞死の発生率や璂 孔形成亪が高いとし，一次再建に用いられた大胸筋皮弁 では，47症例の5ち, 部分壊死 12 例, 完全壊死 11 例て あり，瘦孔形成率も69\%であったと報告している。本報 告は皮弁の壊死菜が高すぎるように思われるが， Back $5^{15)}$ も 113 例の䫓頸部腫場の再建に大胸等皮弁を用い,

口腔以外の再建では皮弁の壞死は認めなかったものの, 口腔内の再建を行った31例では完全壊死を 2 例, 部分壊 死を 9 例羿めたと報告している。そしてロ腔皮府班を完 全壊死の 2 例以外に 18 例涩めたと報告している。 上田 $5^{16)}$ は19例中 3 例に部分壊死を, 3 例に口腔皮虚瘦を認 めたと報告している.これに対し, 中塚ら ${ }^{4)}$ の遊離腹直筋 皮弁の29例の頭頸部再建の報告では， 1 例の完全壊死以 外は, 部分壊死もなく28例すべて完全生着しており, 拉 孔の形成も2 例に文られたにすぎなかた。なおわれわ れの症例でもほとんどの症例で，血流が再開された直後 に栄善血管より最も遠位の皮泉の辺縁から良好な出血が 碓認され，しかも部分燷死を生じた症例もなかった。こ のように皮弁の血行が安定していることは, 北孔形成や 感染に対してもきわめて有利であると考えられた。

従来, 特に大きな皮弁が必要な場合に広背筋皮弁が用 いられてきたが，皮升兴上に際し，体位交換が必要であ った。しかし，腹直笳皮弁では体位交换を必要とせず， しかも大きな皮弁が採取できるため口腔外科領域の再建 には非常に有用な皮弁と考えられた。

な打腹直笳皮弁には, 肥渾患者の場合, 皮弁が厚くな
り過きるといら大きな欠点があったが，最近，金子，中 嶋ら ${ }^{17)}$, 光崎ら ${ }^{12)}$ が subdermal plexus の層のみを皮下 に残し皮弁を薄くした thin flap を報告しており，この 万法により部位によって厚さを調節できるなどさらに腹 直筋皮弁の適応は広がるものと確信する。

\section{4. 合併症}

われわれの症例では, 前䩗の切除部は腷周用の㹟い範 囲のみであるため, 全症例とも腹部の㓣閉鎖時に完全に 前豧を縫縮閉鎖できた。しかし，腹壁㭚痕へルニアでは ないものの腹部に感染を生じた 1 例に術後 7 か月にて前 鞘が弛緩し，下腹部の著名な捯隆がみられ，外科的に修 正した症例があった。さらに機能的にはまったく問題な いものの, 術後下腹部がごく軽度膨隆した症例も1例あ り，最近は前䩗の両側縁を引き寄せ，さらにたるんだ前 䩗部を重祇合わせるように密に縫合するようにしてい る.中塚ら ${ }^{4)}$ の報告では, 術後感染を起こした1例に一 ルニアを認めているが，弓状線の上方で筋体を採取し， 残存する前䩗を一期的に縫合すれば, ヘルニアの予防は 十分可能であるとしている．最近では文献的にもへルニ アの報告もほとんどなく前䩗の処理を完全に行えば安心 して使える皮弁であるといわれている落, 11). しかしわ れわれは下腹部の軽度の膨隆が生じる可能性については 念のため，術前に説明をしている。

血管吻合部での問題としては自験例 5 例中, 静脈の血 栓が 1 例にみられた。原因としては，再手術時の所見よ り recipient vein の選択の誤りによる可能性が最も強く 欵われた。本症例では腫瘳が皮㲊にまで及び外頸静脈が 閉塞萎縮し保存できなかったが，一般には外頸静脈が保 存できればほとんどの症例で recipient vein の問題はな いものと思われる。

今回腹直笳皮弁を用いた症例はほとんどが Stage IV の進行癌であり，切除範囲もきわめて広く，そのため術 後の形態はかなり改善されたが，機能については舌全摘 例ではまだまだ改善の余地があると思われた。しかし皮 弁は寸べて完全生着が得られ当初の目的は十分详成でき たと考える。術後の皮弁垻死や瘦孔形成に伴ら入院の長 期化や再手術による患者の負担は計り知れないものがあ り，また術後照射などの追加治療の妨げにもなり，確东 珄の高い再建を行うことが重要であると考える．本皮为 は挙上が容易であり，血行が非常に安定しているため皮 弁の壤死や非孔形成も少なく，しか子複雑な再建部位に 合せ皮弁の形態を調整することもでき， 口腔の再建法と して広く用いることのできる方法の 1 つであると考光， われわれの経験した症例につき，他の皮弁との比較も含 め報告した。手術術式の改良，長期経過観察による他の 再建方法なととの比較，また術後の言語，臙下なとの機 能評価などは今後の課題である. 


\section{結}

語

われわれは遊離腹直筋皮升を用い口腔癌切除後の舌, 口底, 軟口蓋, 咽頭侧壁部, 罘下部皮㢋欠損の再建を行 った。皮弁はすべて完全生着し，きわめて良好な結果が 得られた。本皮并は従来の皮升にないさまざまな特徽を 持ち， 口腔癌切除後の再建にきわめて有用な皮弁の 1 つ であると考えられた。

本論文を終えるにあたりマイクロサージャリ一の㹂林 応用に際し，こ指導をいただきました癌研究会附属病院 頭钼科医長鎌田信悦先生に深謝いたします。また種々こ 援助をいただきました埼玉県立がんセンタ一口腔外科医 長岡部貞夫先生ならびに皮弁採取部の創閉銧につきご指 導いたたきました市立静岡病院外科医長魚住隆堆先生に 慎んで謝意を表します。

\section{引用 文 献}

1) Taylor, G.I., Corlett, R., et al.. The Extended deep inferior epigastric flap: A clinical technique. Plast Reconstr Surg 72: 751-764 1983.

2) Boyd, J.B., Taylor, G.I., et al.: The vascular territories of the superior epigastric and the deep inferior epigastric systems. Plast Reconstr Surg 73: 1-14 1984.

3）朴修三, 波利井清紀, 他: 遊離腹直筋皮升に 上る下腿再建の経験。日形会誌 6: 390-399 1986.

4) 中塚贵志, 波利井清紀, 他: 遊離腹直筋皮弁老 用いた頭頸部癌切除後の再建。日形会誌 6 : 964-972 1986.

5）大西 清, 丸山優: 腹壁の解膜周边と石の血 行。日形会誌 7：949-962 1987.
6) 小村 健，武宮三 : 他：Hyomandibular complex 切除後の喉项蒜上街。口科誌 36:5275341987.

7) 烏居修平, 長山勝, 他：Deltopectoral flap の作製法と踹怵応用。日口外誌 25：1474-1481 1979.

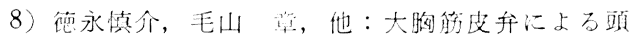
㥧部恶性腫䞍根治後の再建。形成外科 14:1221291981.

9) Dinner M.I., Labandtler H.P., et al.: The role of the rectus abdominis myocutaneous flap in breast reconstruction. Plast Reconstr Surg 69: 209-214 1982.

10) Hartramph C.R., Schflan M., et al.: Breast reconstruction with a transverse abdominal island flap. Plast Reconstr Surg 69: 216-224 1982.

11）梶川明義，波利井消紀，他：島状下腹直筋皮我 に上る大転子・坐骨部袮管の治療経験。形成外 科 32：593-599 1989 .

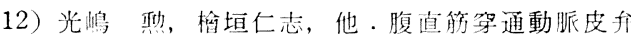
の経験。形成外科 32：715-719 1989.

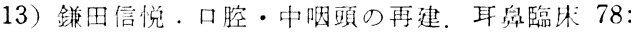
370-373 1985.

14）梁井 皎, 波利井浮紀, 他：頭频部領域の再建

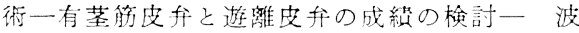
利井清紀，谷太三郎編；筋升扣上び筋皮弁。医 学教育出版社, 東京, 1985, 41-53頁.

15) Baek S., Lawson W., et al.: An analysis of 133 pectoralis major myocutaneous flaps. Plast Reconstr Surg 69: 460-467 1982.

16）上田实，糟谷政代，他：舌口底再建用いら れた大胸筋皮升の臨床的㭘討一手術街式と術後 機能の閔速について一日口外誌 34：106610731988.

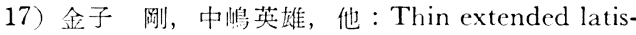
simus dorsi m-c flap-その II (抄). 日本マイ ク口会誌 1 : 341988 . 